AJChE 2013, Vol. 13, No. 2, $57-72$

\title{
Optimization Study of the Solid Propellant [Rocket Fuel] Based on Extracted Bitumen of Indonesian Natural Buton Asphalt
}

Bardi Murachman *,1

Sajono ${ }^{2}$

Fauzan Afandi ${ }^{1}$

Johan Khaeri ${ }^{1}$

${ }^{1}$ Laboratory of Petroleum, Gas and Coal, Department of Chemical Engineering, Faculty of Engineering, Universitas Gadjah Mada, Jalan Grafika No.2, Yogyakarta 55281, Indonesia

${ }^{2}$ Mechanical Engineering Department, Universitas Gadjah Mada, PT Data Reka Inertia, Jakarta

*e-mail : bmurrachman@chemeng.ugm.ac.id

The asphalt propellant for rockets has been investigated since 1960. This material has been developed with the variation of fuels, oxidizer, binders, metal elements and additives. As solid propellant, it has some advantages and disadvantages during the implementation.At present, Extracted Buton asphalt has been studied as an alternative propellant fuels. It is a natural asphalt, extracted from Buton island asphalt rock. When the extract of buton asphalt is mixed with oxidizer, binder, and metal powder, it can be functioned as propellant which is able to release high intensity of energy, have strong thrust and power to fly the rocket. This optimization study of solid propellant was conducted by mixing the Buton asphalt as fuel, oxidizer, metal element and other additives to form a solid propellant. The oxidizer consisted of potassium nitrate $\left(\mathrm{KNO}_{3}\right)$ and potassium perchlorate $\left(\mathrm{KClO}_{4}\right)$. The variations of $\mathrm{KClO}_{4} / \mathrm{KNO}_{3}$, propellant density and the ratio of the nozzle diameter were also conducted in order to find the best propellant composition and the optimum operating conditions to produce enough power while maintain the integrity of the rocket.The main parameters such as the propellant's thrust $(\mathrm{F})$ and the specific impulse ( $\mathrm{I}_{\mathrm{sp}}$ ) were examined. The results showed that higher composition of $\mathrm{KClO}_{4} / \mathrm{KNO}_{3}$ gave the higher value of the thrust and the specific impulse. $\mathrm{KClO}_{4} / \mathrm{KNO}_{3}$ levels above the 1:1 ratio produced an explosive properties at the time of ignition. The tendency of propellant to explode during ignition process was also observed. The optimum condition was obtained at the $\mathrm{KClO}_{4} / \mathrm{KNO}_{3}$ ratio of $1: 1$, the propellant density was $1.900 \mathrm{~g} / \mathrm{cm}^{3}$ and $\mathrm{Ae} / \mathrm{A}^{*}$ was 3.33 . These conditions generated impulse value that last for 277.07 $\mathrm{s}$, average thrust of $14.082 \mathrm{~N}$, and average rate of combustion of $0,24 \mathrm{~cm} / \mathrm{s}$. Therefore, it can be concluded that propellant with fuel from extracted of Buton asphalt can be used as an alternative propellant for rocket.

Keywords: Buton asphalt, solid propellant, potassium perchlorate, propellant density, the ratio of the diameter of the nozzle, potassium nitrate 
58 Optimization Study of the Solid Propellant (Rocket Fuel) Based on Extracted Bitumen of Indonesian Natural Buton Asphalt

\section{INTRODUCTION}

Boomed rocket technology and its use have penetrated many areas which also includes development of propellants as rocket fuel. Various propellants have been developed in many countries such as USA, Russia, European countries, and Japan, as well as Asian countries such as Iran, Pakistan, India, and North Korea in order to meet the needs of the world rocket demand. In rocket weaponry, the name of Exocet, Sidewinder, Tomahawk, Sparrow, have been widely known.

From its physical properties, the types of propellant that consist of solid propellant, liquid, and hybrid (solid-liquid) have their own advantages and weakness on their applications. In general, the material composition of propellant becomes intelectual property of the producers. At present, Indonesia is left behind in the development of rocket technology, even though many weapons is already old fashioned and expired. On the other hand, the import of rocket fuel is relatively expensive and difficult due to the regulation of the manufacturing country.

Buton asphalt is a natural resource which is found in Buton Island. The structure and chemical properties, which is composed of rich material elements of hydrogen and carbon, has potential value as energy source. Mixing it with the oxidizer makes this material able to release high energy and have strong energy to push the rocket. The aim of this study was to find the optimum condition/performance of the propellant from extracted Buton asphalt.

\section{BASIC THEORY}

Asbuton is natural asphalt in the form of rock mixed with soil minerals which can be extracted by using various solvents. The content of bitumen asphalt in Buton Island (Kabungka and Lawele) varies from 25 to $35 \%$.

Generally, Asbuton is used as road asphalt. Nevertheless, Buton asphalt has a somewhat different nature from petroleum asphalt from refining process. Bitumen is a complex compound, mainly composed by hydrocarbons and small amount of atom $\mathrm{N}$, $\mathrm{S}$ and $\mathrm{O}$, trace metals such as vanadium, $\mathrm{Ni}$, $\mathrm{Fe}, \mathrm{Ca}$ in the form of organic salts and oxides. The elements contained in the bitumen are Carbon: 82-88\%, Hydrogen: 8$11 \%$, Sulfur: $0-6 \%$, Oxygen $0-1.5 \%$, and Nitrogen: 0-1\% (Murachman, 2009).

The structure of their saturates, aromatics, resins and asphalteness are as follows (Nuryanto, 2008). Asphaltenes is composed of aromatic and aliphatic chains with large molecular weight 1000-100,000. Aromatics are composed of aromatic and aliphatic chains with a simpler structure and smaller molecular weight, whereas the saturates and aliphatics are composed of cyclic and aliphatic chain structure with a simpler structure and low molecular weight as shown in Figure 1.

The most important part of the rocket which is directly related to the propellant is the motor of the rocket (Mugia, 1996). In order to meet the requirement to fly, this part should have the following characteristics (Fesna et al., 2005): 
<smiles>[R]C1=C([R])C([R])C([R])=C2C3=C1C([R])C1[C+]3C([R])(C2[R])C([R])C([R])C1[R]</smiles><smiles>[R]C1=C([R])C([R])C([R])=C([R])C1[R]</smiles>

\section{Aromatics Structure}

\section{Asphlatenes, R : aliphatic naphthenic or aromatic carbon chain}

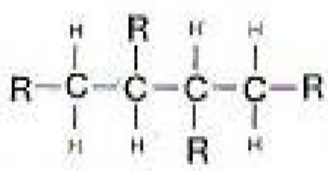

Saturates Structure, C: carbon, $\mathrm{H}$ : hidrogen, $\mathrm{R}$ : rantai carbon Aliphatic naphthenic

Fig.1: Structure of Asphaltenes, Aromatics, and Saturates of Buton asphalt.

1. Burning time $\left(t_{b}\right)$ is quite wide and the motor thrust force $(F)$ is not too big, because if $F$ is too large, it can result in considerable acceleration of the rocket motion. This situation is not expected because it will produce acceleration equal to the gravity. As a result it will damage the instrument payload. Larger $F$ will increase the Mach number, where Mach number approaches one (1) is also not expected, because it make the largest drag.

2. Combustion chamber pressure $(P)$ is small, because when $P$ is small, then the pressure in the combustion chamber in the radial direction is low, therefore the needed motor tube is thinner. Good rocket motors have a light motor, but propellant mass is quite a lot (Mugia, 1996). So it is expected that the charge to be carried by rocket can be heavy.
3. A low of combustion temperature $\left(T_{c}\right)$. Here at a small combustion chamber, the heat insulator material of the tube (liner) will be thinner, hence the motor can be lighter. A higher $T_{c}$ can result in large propellant melt, so the pressure can result in configuration change and it will not comply with the design requirement, and it can also cause considerable erosion rate.

4. High specific impulse $\left(I_{s p}\right)$, because the greater value of $I_{s p}$ shows more efficient rocket motors.

5. Sliver percentage is quite small. Sliver is the remainder of the burning propellant, after the propellant burns reaching liner. Sliver combustion produces pushing force that continuously declines, so the resulting pushing force is quite small, and it is not effective to propel the rocket. A smaller sliver means that the 
60 Optimization Study of the Solid Propellant (Rocket Fuel) Based on Extracted Bitumen of Indonesian Natural Buton Asphalt

mass propellant which produces effective pushing force becomes larger, therefore the wasted energy is quite small.

\section{Solid Propellant Combustion Process}

In general, the reaction during the launch of the rocket is oxidation between fuel and oxidizer, which is driven by the heat/flame. Without the existence of those three materials, oxidation or combustion does not occur. For fuel, the fastest burning speed is the gas fuel, then the liquid fuel. Meanwhile the solids have the lowest burning speed. For solid propellant, the burning speed depends on the mixture of the fuel, oxidant, and fillers as well as other additional ingredients. Slow burning rate produces low pressure and pushing force of burning material, on the other hand a very fast burning rate produces powerful pushing force, and even it can blow out the rocket motor itself. Thus, it is necessary to find the optimum conditions to fly the rocket, by considering the risk of damaging the rocket itself.

\section{Combustion Rate}

Propellant is usually burned in parallel layers. The amount of the consumed propellant and the amount of the formed gas are proportional to the surface of the burning propellant as shown in equation (1).

$$
\frac{d m}{d t}=r \cdot \rho \cdot A_{b}
$$

where $d m / d t$ is the mass burning rate $(\mathrm{g} / \mathrm{sec}), r$ is the burning rate $(\mathrm{cm} / \mathrm{sec}), \rho$ is density $\left(\mathrm{g} / \mathrm{cm}^{3}\right)$ and $A_{b}$ is the propellant surface area $\left(\mathrm{cm}^{2}\right)$. Burning rate is affected by the temperature of propellant, the pressure produced by propellant burning, and it is also influenced by the composition, the geometrical configuration and the size of the particle as well as the way the combustion flows from the surface.

\section{Rocket Pushing Force}

Rocket thrust is important variable in determining the performance of the rocket. Under a particular known thrust, we can estimate the weight of cargo that can be transported and dynamics of rocket flight in accordance with the specified trajectory.

\section{Specific Impulse}

Specific impulse is a significant amount in which rocket's performance and efficiency can be characterized by a bigger specific impulse. The specific impulse value $\left(I_{s p}\right)$ can be determined by equation (2).

$$
I_{s p}=\frac{\sum_{0}^{j} F_{j} \Delta t}{m_{p} g}
$$

From equation (2), it is shown that the $I_{s p}$ is larger if the rocket with propellant mass $\left(m_{p}\right)$ is as small as possible. Therefore it can produce a bigger thrust with long combustion time.

\section{Nozzle}

The most prominent function of nozzle is to increase the pressure ratio inside the rocket tube at atmosphere pressure (James et al., 1966; Johnston et al., 1966). In this case, the combustion gas discharge rate is expected to increase as maximum as possible. To achieve that condition, the nozzle design and geometric must be 
carefully considered. The type of rocket nozzle geometric is generally known as conical and cubical. To design the nozzle geometric, there must be an effort, whereas the effect of friction is minimum and under an adiabatic condition.

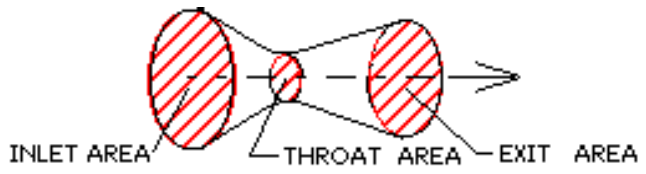

Fig.2: Nozzle geometry

The speed of nozzle output is calculated by using the equation below

$$
V_{e}=\sqrt{2 T_{o}\left(\frac{R^{\prime}}{M}\right)\left(\frac{k}{k-1}\right)\left[1-\left(\frac{P_{e}}{P_{o}}\right)^{\frac{k-1}{k}}\right]}
$$

\section{EXPERIMENTAL}

The materials used in this study was the extracted natural Buton asphalt, potassium perchlorate $\left(\mathrm{KClO}_{4}\right)$ and potassium nitrate $\left(\mathrm{KNO}_{3}\right)$ as oxidizer, sucrose and carbon as auxiliary material, sulfur and aluminum powder as catalist and a solvent to dissolve and homogenize the propellant mixture. (Bakhman et al., 1974)

The equipment used in the present experimental study consisted of rocket engine and a series of rocket static test equipment, as shown in Figs. 3 to 6.

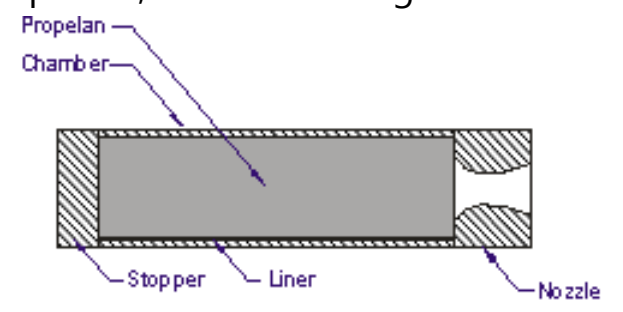

Fig. 3: The scheme of Rocket machine

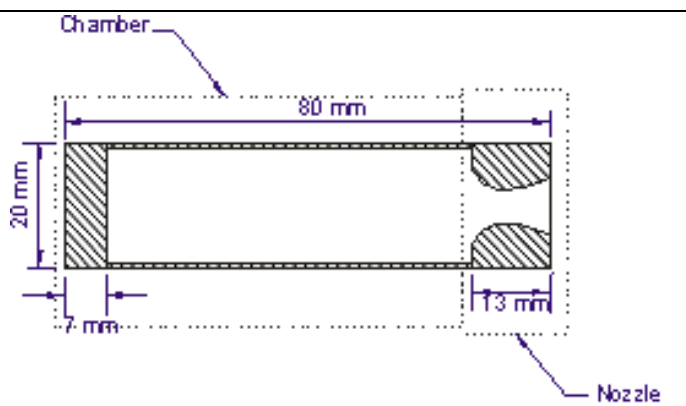

Fig. 4: The configuration of rocket machine

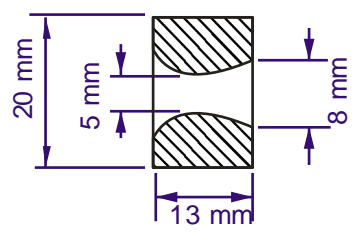

Fig. 5: Nozzle Configuration.

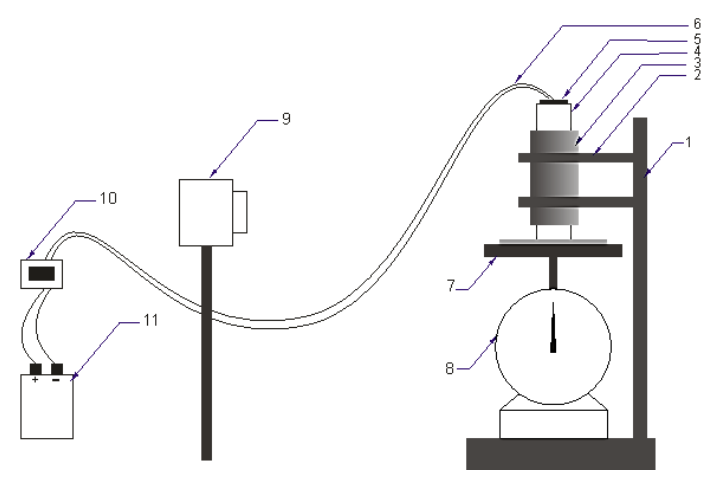

Fig. 6: The schematic diag of the burning test equipment. Note : 1._Stative, 2. Clamp, 3. Tube support, 4. Rocket Motor, 5. Nozzle, 6. Ignition cable, 7. Suport plate, 8. Balance, 9. Camera records, 10. Ignition Conector, 11. DC current source.

The propellant was prepared by blending $15 \mathrm{~g}$ bitument, $5 \mathrm{~g}$ sucrosa, $5 \mathrm{~g}$ sulphur, $5 \mathrm{~g}$ Carbon, $5 \mathrm{~g} \mathrm{Al}$ powder and 75 $\mathrm{g}$ oxidizer. The variation of oxidizer ratio $\left(\mathrm{KClO}_{4}\right.$ to $\left.\mathrm{KNO}_{3}\right)$ of $4: 1 ; 3: 1 ; 2: 1 ; 1: 1 ; 1: 2 ; 1: 3$; $1: 4$, and $100 \% \mathrm{KNO}_{3}$ were employed. For the composition of $1: 1$, the amount of $\mathrm{KNO}_{3}$ was $37,5 \mathrm{~g}$ and $\mathrm{KClO}_{4}$ is $37,5 \mathrm{~g}$. For comparison, the composition of 1:2 needs $\mathrm{KNO}_{3} 50 \mathrm{~g}$ and $\mathrm{KClO}_{4} 25 \mathrm{~g}$, and so forth. 
62 Optimization Study of the Solid Propellant (Rocket Fuel) Based on Extracted Bitumen of Indonesian Natural Buton Asphalt

Each material was ground by using porcelain grinder, then screened by 150 mesh. Afterwards, the fine material was placed and spread on wide and flat surface, which must be thin and even. The mixture was kept at room temperature and far from fire. Three gram of asphalt was dissolved into hexane, then was mixed with propellant materials. The mixture was placed in a wide and flat area to accelerate the evaporation of hexane. The hexane evaporation was around 30 minutes to make sure that hexane was completely running out. The mixed material and binder was placed in testing equipment.

The variation of propellant density was carried-out by compressing the mixed material under an optimum oxidizer ratio obtained from the previous experimental step in different thickness in order to get different density. The density variation were $2.148 \mathrm{~g} / \mathrm{cm}^{3}, 2.005 \mathrm{~g} / \mathrm{cm}^{3}, 1.879 \mathrm{~g} / \mathrm{cm}^{3}$, $1.671 \mathrm{~g} / \mathrm{cm}^{3}$, and $1.503 \mathrm{~g} / \mathrm{cm}^{3}$.

The variation of nozzle-tube diameter ratio was conducted at the value of $\mathrm{Ae} / \mathrm{A}^{*}$ about 10, 5, 3.33, 2.5 and 2 respectively for propellants with optimum composition (optimum oxidizer ratio) and density.

\section{Ignition Test}

Ignition test was conducted in the bunker in Chemical Engineering Department, Faculty of Engineering, Universitas Gadjah Mada. Before the preparing of the ignition, there must be igniter preparation. The igniter used was a series of electricity DC 12 Volt with electrical input $2 \mathrm{~A}$ connected to a filament equipped with the ignition powder. A recording camera was placed around 2 meters from the test equipment. At the beginning, the balance's scale must show zero. Before starting the test, people around the bunker must be notified. The camera would record ignition process and the balance's scale, which can be used to calculate the thrust in $g$ mass.

\section{Data Analysis}

\section{Determination of Burning Time $\left(t_{b}\right)$}

Burning time is determined by (final time of burning - initial starting burning), where initial and final time was determined visually, i.e. by looking at the fire visibility.

\section{Determination of Burning Rate (R)}

Burning rate (R) was approached as a polynomial equation of order 2 of the time function, which was obtained from the combustion test data. $\mathrm{R}$ can be obtained from the equation of

$$
r=a \cdot t_{b}^{3}+b \cdot t_{b}^{2}+c \cdot t_{b}+d
$$

whereas

$R=d r / d t_{b}=3 a \cdot t_{b}^{2}+2 b \cdot t_{b}+c$

in which $r$ is radius of propellant grain hole, and $a, b, c, d$ are the experimental constants.

\section{Determination of Propellant Mass Reduction Rate (dm/dt)}

The propellant mass reduction rate can be determined from the equations as follows.

$$
\frac{d m}{d t}=A \cdot \rho \cdot R
$$




$$
\begin{aligned}
& \frac{d m}{d t}=2 \pi \cdot r \cdot L \cdot \rho \cdot \frac{d r}{d t} \\
& d m=2 \pi \cdot L \cdot \rho \cdot r d r \\
& \int_{m 0}^{m} d m=2 \pi \cdot L \cdot \rho \cdot \int_{r 0}^{r} r d r \\
& m-m_{0}=\pi \cdot L \cdot \rho \cdot\left(r^{2}-r_{0}^{2}\right) \\
& \Delta m=\pi \cdot L \cdot \rho \cdot\left(r^{2}-r_{0}^{2}\right)
\end{aligned}
$$

Here $r$ is a function of time.

\section{Determination of Thrust (F)}

The thrust is determined by evaluating the images recorded by a video camera. By assuming that combustion speed is constant during the ignition, therefore, the thrust value can be calculated by equation (12) as follow.

$$
F_{n}=\left(D-m_{p}+d m\right) g=\left(D-m_{p}+A \rho R\right) g
$$

where $F_{n}$ : Thrust Value (N)

$$
\begin{aligned}
& D \text { : Thrust }(\mathrm{kg}) \text { evaluated every } \\
& 0,1 \mathrm{~s} \\
& m_{p} \quad \text { : Baseline propellant mass }(\mathrm{kg}) \\
& d m \text { : Reduction mass due to the } \\
& \text { propellant burning }(\mathrm{kg}) \\
& g \text { : Gravity acceleration (9.81 } \\
& \mathrm{kg} \cdot \mathrm{m} / \mathrm{s}^{2} \text { ) } \\
& A \text { : Area of burning surface }\left(\mathrm{m}^{2}\right) \\
& \rho \quad \text { : Propellant density }\left(\mathrm{kg} / \mathrm{m}^{3}\right) \\
& R \quad \text { : Combustion speed (m/s) }
\end{aligned}
$$

\section{Determination of the Total Impulse $\left(I_{t}\right)$}

The total impulse can be calculated by the following equation.

$$
I_{t}=\int_{0}^{t_{b}} F d t
$$

where $I_{t}$ is the total impulse $(\mathrm{N}-\mathrm{sec})$, and $t_{b}$ is burning time (sec). The above integration can be solved numerically by using the trapezoidal rule method:

$$
I_{t}=\frac{\Delta t}{2}\left(F_{0}+2 F_{1}+2 F_{2}+\ldots+2 F_{n-1}+F_{n}\right)
$$

\section{Determination of Average Thrust ( $F_{\text {avg }}$ )}

The average thrust, $F_{\text {avg, }}$ can be directly calculated by using equation (15).

$$
F_{\text {avg }}=\frac{I_{t}}{t_{b}}
$$

\section{Determination of Spesific Impulse (Isp)}

The average specific impulse, $l_{s p}$, can be directly calculated by using equation (16).

$$
I_{s p}=\frac{I_{t}}{m_{p} \cdot g}
$$

\section{RESULTS AND DISCUSSION}

\section{Effect of Oxidizer}

The obtained ignition images of propellant at various composition of oxidizer are shown in Figure 7, in which (a), (b), (c), and (d) corresponds to the cases of the oxidizer composition ratio of 1:1, 1:2, 
64 Optimization Study of the Solid Propellant (Rocket Fuel) Based on Extracted Bitumen of Indonesian Natural Buton Asphalt

$1: 3$, and 1:4 respectively. Those images were visually analyzed, and the results is discussed in the following section.

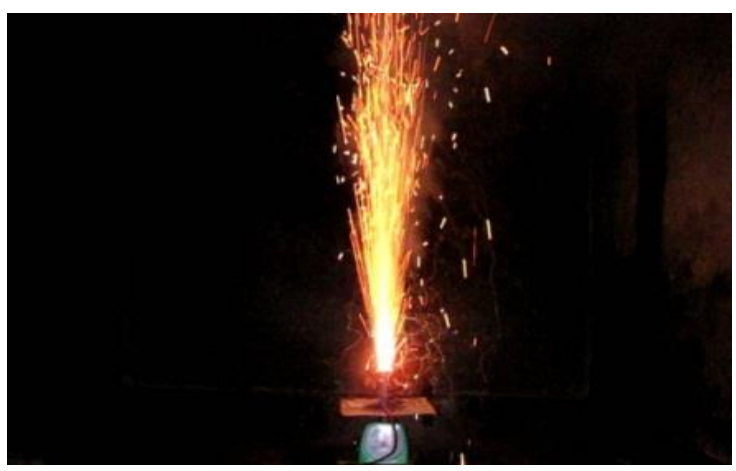

(a)

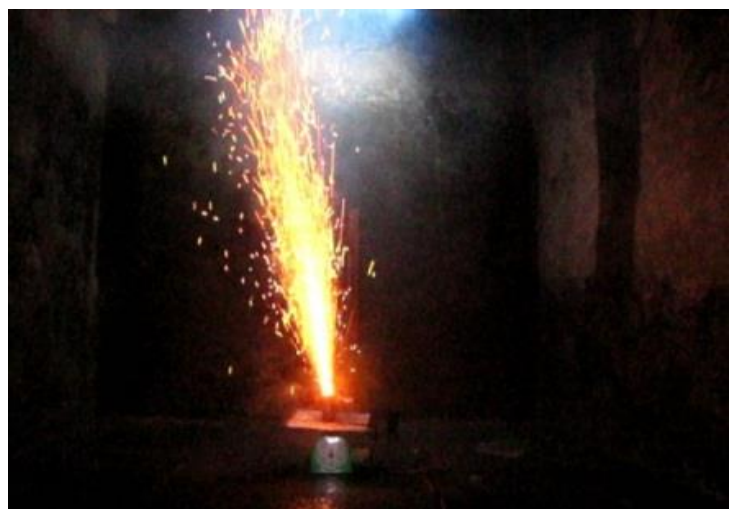

(b)

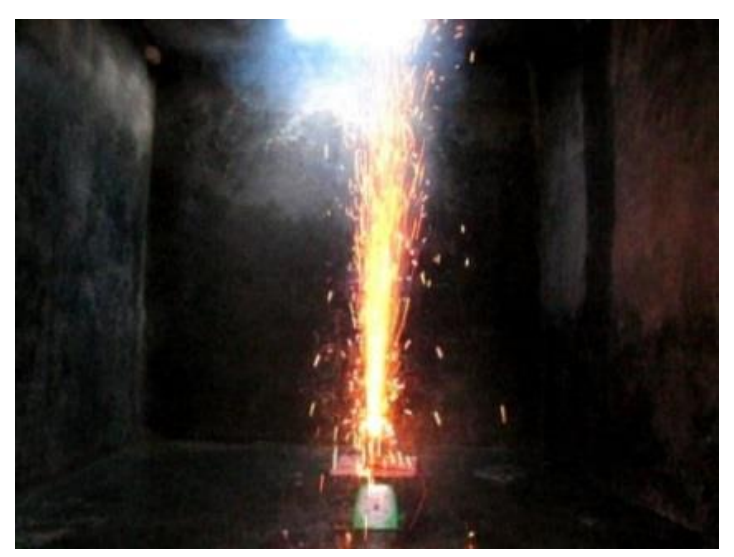

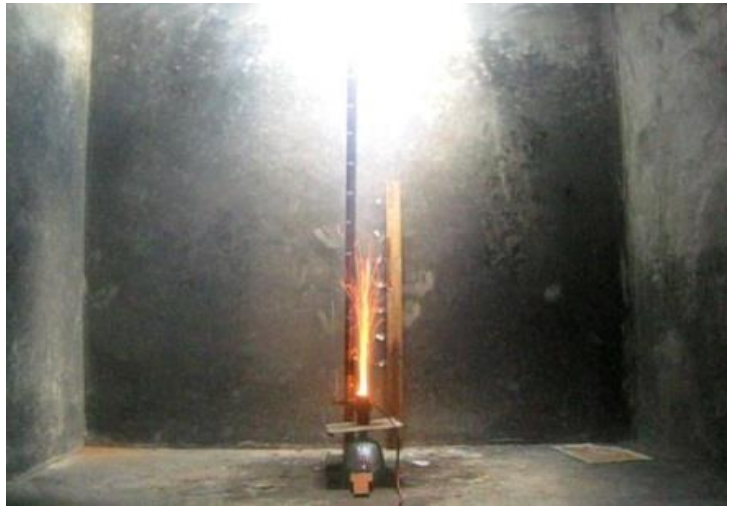

(d)

Fig.7: The sample of images taken from the burning test for the variety of $\mathrm{KClO}_{4}$ and $\mathrm{KNO}_{3}$ (Oxidizer) composition ratio (a) $1: 1$, (b) $1: 2$, (c) $1: 3$, (d) $1: 4$.

From the ignition test, the main result is shown in Figure 8 . This figure reveals that higher ratio of potassium perchlorate propellant to potassium nitrate gives greater average thrust and faster burning time. This is due to the oxidizer of potassium perchlorate, which is a stronger oxidizer than potassium nitrate. Potassium perchlorate oxidizes better than $\mathrm{KNO}_{3}$. The $\mathrm{Cl}$ element of $\mathrm{KClO}_{4}$ has greater electronegativity than $\mathrm{N}$ of $\mathrm{KNO}_{3}$, hence the ability of $\mathrm{Cl}$ to attract electrons from other compounds is greater than N. Moreover, $\mathrm{KClO}_{4}$ produces more $\mathrm{O}_{2}$ than $\mathrm{KNO}_{3}$, as shown by the following reaction.

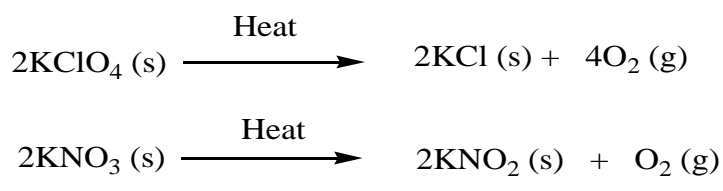

(c) 
In $\mathrm{KClO}_{4}$ decomposition reaction, all oxygen can be released completely, while in the $\mathrm{KNO}_{3}$ decomposition, not all of oxygen can be released.

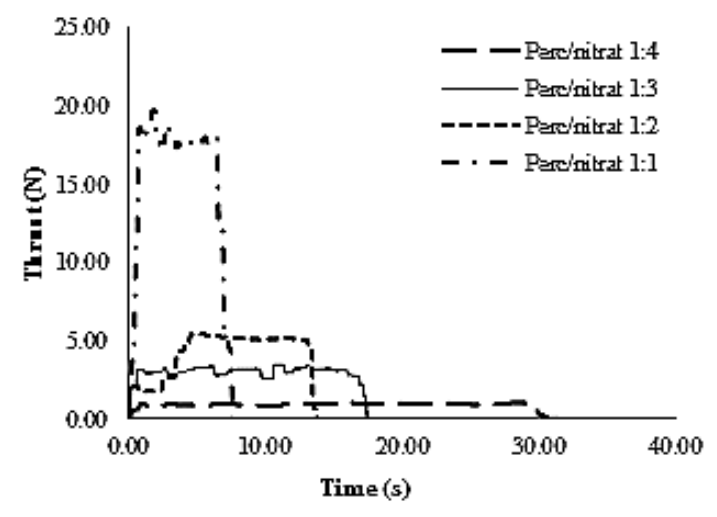

Fig.8: The data of thrust measurement at various oxidizer ratio.

Potassium perchlorate is a very strong oxidizer, which can oxidize bitumen well. However, when the amount of perchlorate in the mixture is high, it become an explosive propellant, due to very high rate of heat of combustion release. This can be seen in the test propellant with $\mathrm{KClO}_{4}$ ratio exceeding $50 \%$ (the ratio is greater than 1:1). Static test of the mixture of propellant oxidizer potassium perchlorate and potassium nitrate at a ratio of $1: 2$ shows that the mixture failed to blast (explode). Blasting occurs because the content of potassium perchlorate oxidizer is too high. As a result, oxidation reaction take places too fast, which releases high intensity thermal energy. High pressure in the rocket motor tube causes rocket tube rupture and explosion. Hence, static test for the oxidizer to propellant mixture of potassium perchlorate and potassium nitrate (ratio $4: 1, \quad 3: 1,2: 1)$ and $100 \%$ potassium perchlorate oxidizer was certainly not be conducted due to its explosiveness.
Meanwhile, the results of the static test propellant oxidizer $100 \% \mathrm{KNO}_{3}$ showed that it has $185 \mathrm{~s}$ burning time, exhaust gas fumes clumping and very small thrust (close to zero, which is not readable). This indicates that $\mathrm{KNO}_{3}$ oxidizer is not able to oxidize bitumen well, where the chain of carbon in the bitumen cannot be decomposed, or the propellant combustion process does not complete.

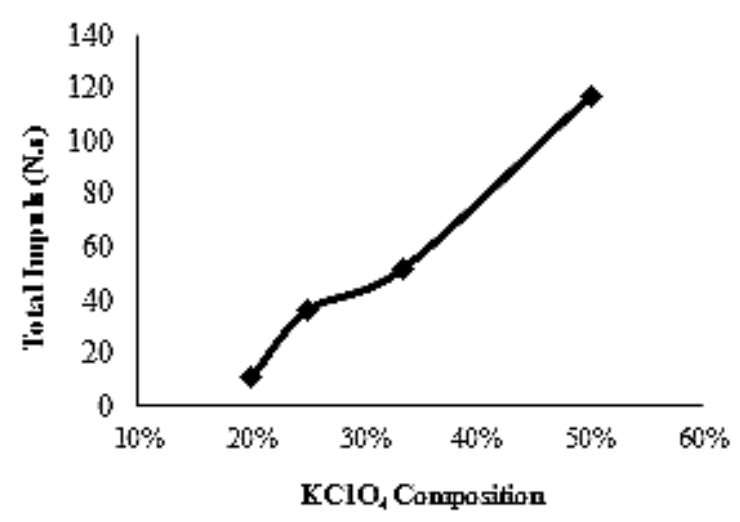

(a) Total Impulse

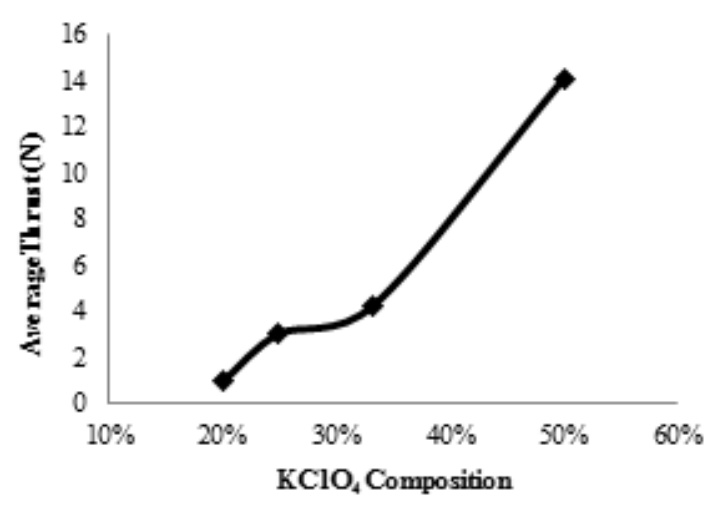

(b) Average Thrust

Fig. 9: The effect of the addition $\mathrm{KClO}_{4}$ in the composition on the average thrust

The addition of $\mathrm{KClO}_{4}$ composition greatly affects the total impulse $\left(I_{t}\right)$ and the average of thrust $\left(F_{\text {avg }}\right)$. The results of the calculation of the total impulse and average thrust can be seen on Figure 9(a) and (b). 
The composition of 1:1 means that the content of $\mathrm{KClO}_{4}$ in the oxidizer mixture is $50 \%$, while for the composition of $1: 3$ means that the content of $\mathrm{KClO}_{4}$ is $25 \%$. The total value of the impulse and average thrust obtained in $\mathrm{KClO}_{4}$ composition of 1:1 are the highest and that of 1:4 are low. In addition, Figure 9 explains also that the greater the $\mathrm{KClO}_{4}$ composition, the higher the impulse and the average thrust will be.

Specific impulse is one of the important parameters that indicate the strength of the propellant. From Figure 10 it can be seen that the greater the $\mathrm{KClO}_{4}$ composition, the greater the value of specific impulse is. Largest value of $I_{s p}$ obtained at the composition of $1: 1$ is $277.07 \mathrm{~s}$, and that of the composition of $1: 2,1: 3$, and $1: 4$, are respectively $122.56 \mathrm{~s}, 86.611 \mathrm{~s}$ and $26.03 \mathrm{~s}$.

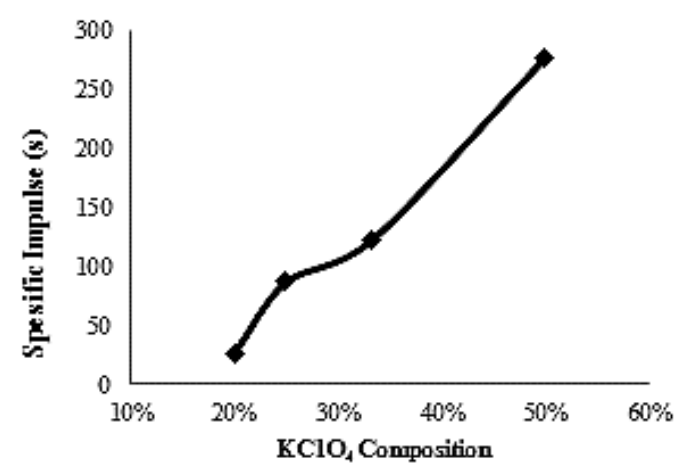

Fig. 10: The effect of addition of $\mathrm{KClO}_{4}$ in oxidizer composition on the specific impulse.
In general, it can be seen that the greater the content of $\mathrm{KClO}_{4}$ oxidizer, the shorter combustion time (tb) as well as the greater thrust and specific impulse are. The best performance amongst four compositions is at the ratio of $1: 1$, which has highest value of thrust, total impulse and specific impulse. When the composition of $\mathrm{KClO}_{4}$ is raised, it causes explosion on ignition process. This results is in line with the trend obtained by Khaeri (2010) where the increase in $\mathrm{KClO}_{4}$ oxidizer in the propellant causes the value of specific impulse and thrust generated increase, but it can cause detonation. The optimum ratio between $\mathrm{KClO}_{4}$ and $\mathrm{KNO}_{3}$ in Khaeri's investigation is $1: 1$.

\section{Effect of the Propellant Density}

Optimum propellant composition (the ratio of the optimum oxidizer) which has been obtained from previous experiments was used to find the optimum propellant density. Obtained propellant composition was: $13.33 \%$ bitumen, oxidizer $66.66 \%$ (33.33\% and 33.33\% $\mathrm{KClO}_{4} \mathrm{KNO}_{3}$ ) and $20 \%$ aluminum metal additives. The density variations to be tested were $2.111,2.000$, 1.900, 1.728 and $1.5835 \mathrm{~g} / \mathrm{cm}^{3}$, with operating conditions, namely static test propellant mass, being $43 \mathrm{~g}$ of propellant and the ratio $A_{e} / A^{*}$ of 3.33 . The resulted thrust obtained for each density variations can be seen in Figures 11 to 13 . 


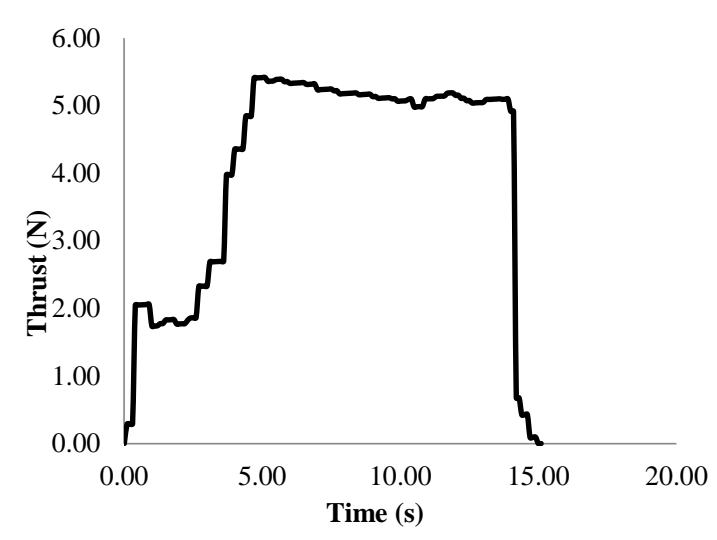

Fig. 11: Thrust vs burning time for the propellant density of 2.111 $\mathrm{g} / \mathrm{cm}^{3}$.

Figure 11 shows thrust versus time curve of the static test results for propellant density $2.111 \mathrm{~g} / \mathrm{cm}^{3}$. The propellant burning time was very short, about $15 \mathrm{~s}$. Flame length was approximately $60 \mathrm{~cm}$, with spark-ignition and black smoke. The results of the static test with a density of $2.111 \mathrm{~g} / \mathrm{cm}^{3}$ shows $5.421 \mathrm{~N}$ of the maximum thrust, with average thrust and total thrust being $4.13184 \mathrm{~N}$ and 504.0844 $\mathrm{N}$ respectively. Impulse total $\mathrm{N}$ was acquired at $50.408 \mathrm{~N}$ and $119.541 \mathrm{~s}$ specific impulse. Propellant performance was still quite low, because the value of the specific impulse was still quite small.

Figure 12 shows thrust versus time curve of the static test results for propellant density $2.000 \mathrm{~g} / \mathrm{cm}^{3}$. Propellant burnt fast, with the time being $15 \mathrm{~s}$. Flame length was approximately $80 \mathrm{~cm}$, with spark-ignition and black smoke. The results of the static test with a density of $2.000 \mathrm{~g} / \mathrm{cm}^{3}$ showed the maximum $8.034 \mathrm{~N}$ of thrust, average thrust and total thrust being $6.50619 \mathrm{~N}$ and $793.756 \mathrm{~N}$ respectively. Impulse total was acquired at $79.376 \mathrm{~N}$ and 188.2 sec specific impulse.

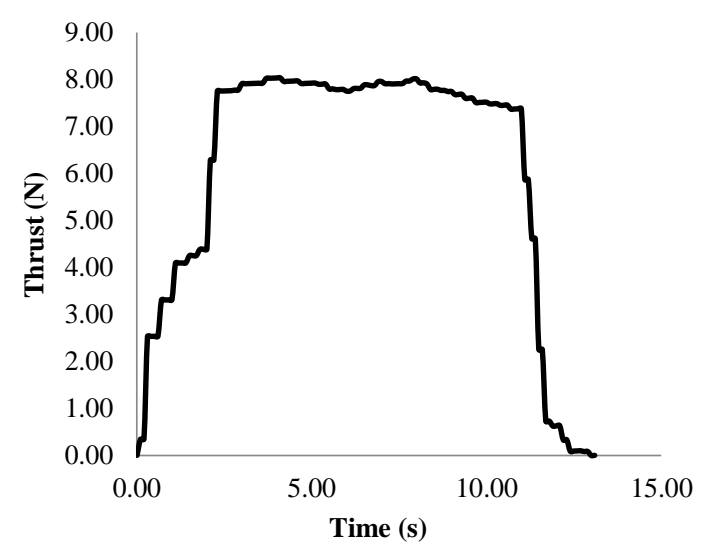

Fig. 12: Thrust vs. burning time for the propellant density of $2.000 \mathrm{~g} / \mathrm{cm}^{3}$.

Experiments on the static test for propellant density of $1.728 \mathrm{gr} / \mathrm{cm}^{3}$ and $1.5835 \mathrm{~g} / \mathrm{cm}^{3}$ have failed due to detonation (explosion). Blasting occured because the propellant density was too low, which had a very high porosity, therefore the propellant burning rate was very high. As a result, the combustion process produced very high intensity energy in the form of high exhaust gas pressure in a short time. The high pressure in the tube made a very large tube walls could not withstand such pressure, which led to explosion.

The results showed that greater density of the propellant makes longer combustion time $\left(t_{b}\right)$, giving smaller value of thrust and smaller specific impulse. It can be seen from figures 13 and 14. 
68 Optimization Study of the Solid Propellant (Rocket Fuel) Based on Extracted Bitumen of Indonesian Natural Buton Asphalt

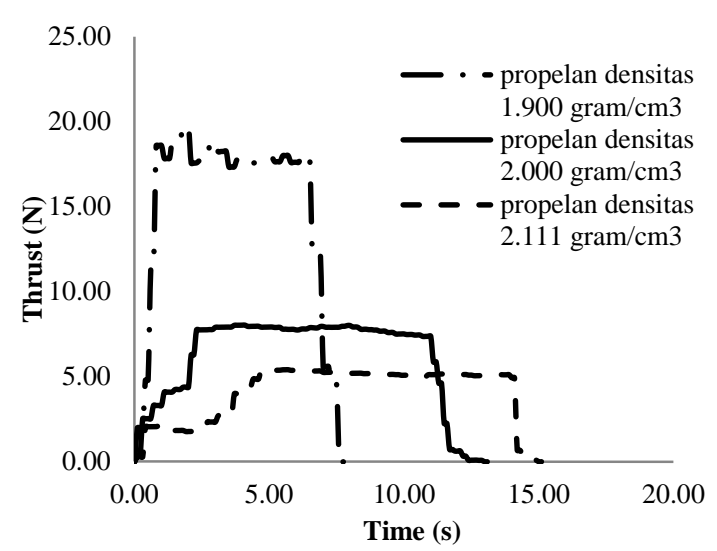

Fig. 13: The thrust measurement resulted from the burning test under the variaton of the propellant density.

Good propellants should have a higher density but still has enough thrust to fly the rocket. Figure 13 shows that greater density of the propellant leads to thrust generated flame getting smaller and longer time. The average of thrust for propellant with density of $1.901 \mathrm{~g} / \mathrm{cm}^{3}$ is relatively large compared to other propellants. It affects the density porosity, which also affects the surface area of the particle combustion. The smaller the propellant density porosity, the larger the surface area is, and consequently burning propellant rate increases and the energy produced is greater. This causes greater generated thrust (Ja'afar et al., 2009).

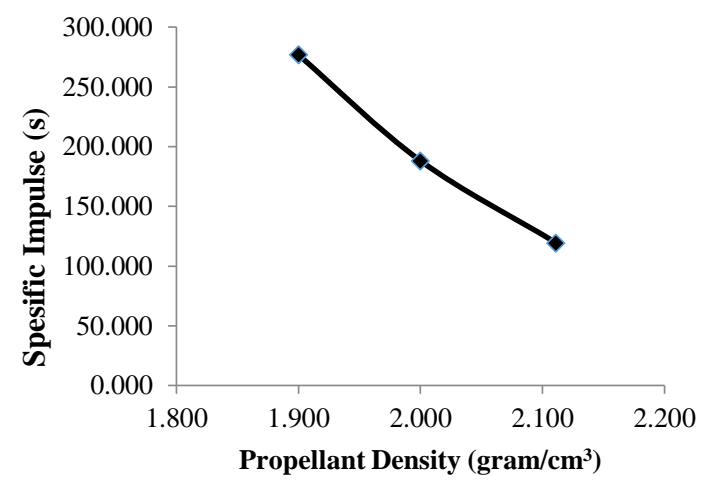

Fig. 14: The Effect of the propellant density on the specific impulse

\section{Effect of Nozzle-tube diameter ratio}

Optimum propellant composition and density (the ratio of the optimum oxidizer) which has been obtained from previous experiments is used to look for the optimum nozzle diameter ratio. Propellant composition obtained is as follows: bitumen $13.33 \%$, oxidizer $66.66 \%$ (33.33\% $\mathrm{KClO}_{4}$ and $33.33 \% \mathrm{KNO}_{3}$ ) and $20 \%$ additives of aluminum metal with density of 1.900 $\mathrm{gr} / \mathrm{cm}^{3}$. Samples printed propellant are put into testing equipment with a nozzle diameter ratio $\left(\mathrm{Ae} / \mathrm{A}^{*}\right)$, respectively 10,5 , $3.33,2.5$ and 2 .

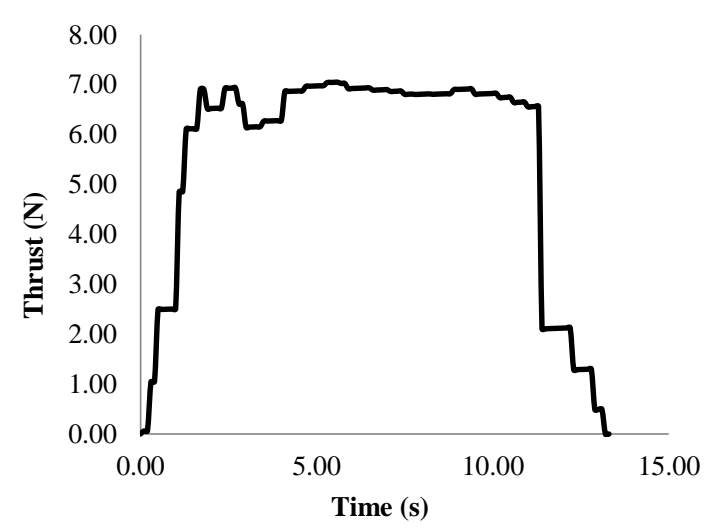

Fig. 15: Thrust (N) vs. burning time for the nozzle ratio of 2 .

Figure 15 shows the thrust versus burning time of the static test results for the nozzle ratio $\left(A_{e} / A^{\star}\right)$ of 2 . Propellant burning time is around $13 \mathrm{~s}$. Flame length is approximately $90 \mathrm{~cm}$, with spark-ignition and a little smoke.

From the analysis of the experimental data indicates that the maximum thrust is $7.052 \mathrm{~N}$, average thrust and total thrust are $5.93842 \mathrm{~N}$ and 724.487 respectively. Total impulse earned is $72.4487 \mathrm{~N}$ and specific impulse is $171.8 \mathrm{sec}$. 


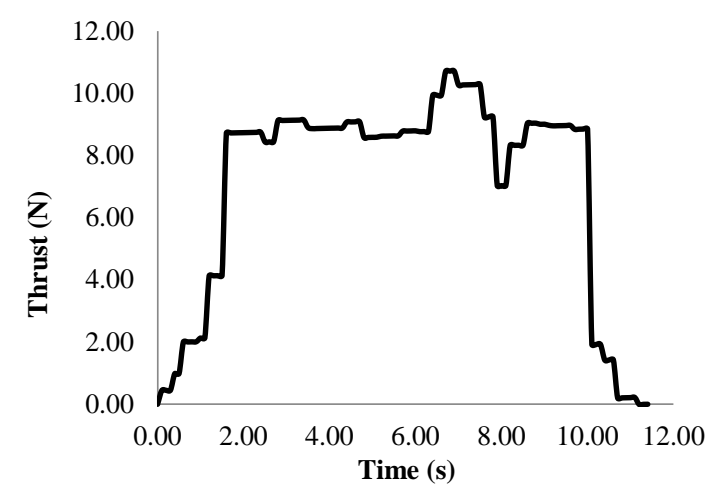

Fig. 16: Thrust (N) vs. burning time for the nozzle ratio of 2.5 .

Figure 16 shows the thrust versus burning time of the static test results at the nozzle ratio $\left(A_{e} / A^{*}\right)$ of 2.5 . Propellant burning time is about $11 \mathrm{~s}$. Flame length is approximately $90 \mathrm{~cm}$, with spark-ignition and a little smoke. The calculations show that the maximum thrust is $10.713 \mathrm{~N}$, the average thrust and total thrust are $6.805 \mathrm{~N}$ and $809.836 \mathrm{~N}$. Total impulse earned is $80.9836 \mathrm{~N}$ with $192.0 \mathrm{sec}$ specific impulse.

The results of the static test using a nozzle propellant ratio $A_{e} / A^{*}$ of 3.33 is shown in Figure 17 . The static test with nozzle propellant ratio $A_{e} / A^{*}$ of 5 and 10 have failed, because explosion occured. Blasting occurs due to very large nozzle ratio $A_{e} / A^{*}$, where the pressure inside the tube increases rapidly. As a result the rocket tubes cannot withstand such high pressure, leading to explosion.

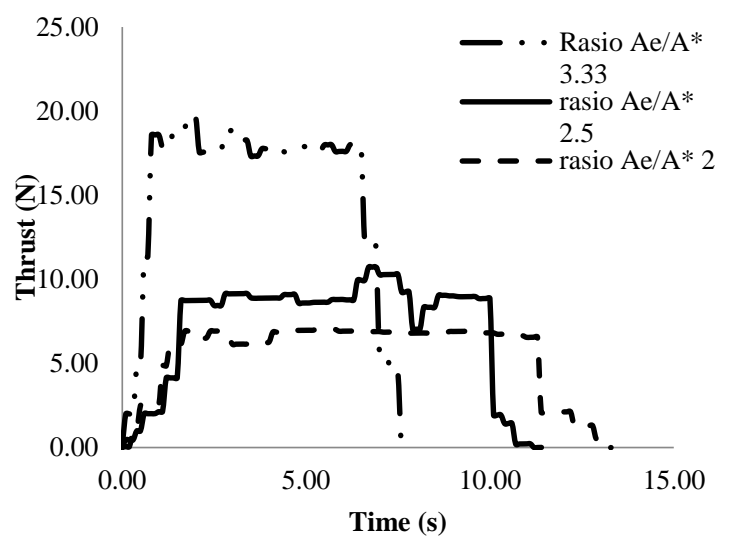

Fig. 17: Thrust (N) vs burning time for the different of nozzle ratio.

The main function of nozzle is to increase the ratio of the pressure inside the rocket tube under atmospheric pressure. Figure 17 shows that the larger the nozzle ratio $A_{e} / A^{*}$, the larger the produced thrust, and the shorter combustion time are. The average thrust at the static test propellant nozzle ratio $A_{e} / A^{*}$ of 3.33 is relatively larger than the static test results from the other propellant nozzle. The greater the nozzle ratio $A_{e} / A^{*}$, the larger the pressure inside the tube is. Consequently, the flue gas velocity at the tube exit increases, hence the thrust also increases.

However, when the nozzle ratio $A_{e} / A^{*}$ nozzle exceeds the maximum expansion ratio, the generated pressure inside the tube becomes higher. If the tube cannot withstand such a high pressure, the tube will rupture or explosion happens. 
70 Optimization Study of the Solid Propellant (Rocket Fuel) Based on Extracted Bitumen of Indonesian Natural Buton Asphalt

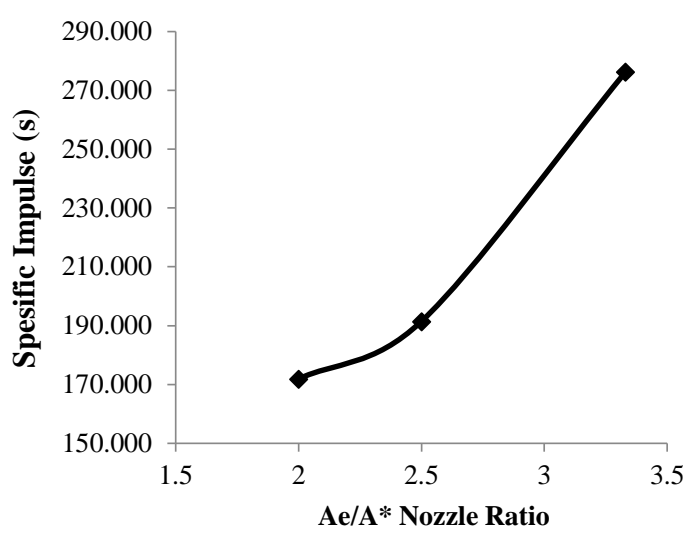

Fig. 18: Relationship between specific impulse and the nozzle ratio

Figure 18 shows the relationship between specific impulse and the nozzle ratio. The figure shows that the specific impulse increases as the nozzle ratio increases.

One of several launching tests that have been performed on the field, and it indicates a good result as shown in Figure 19.

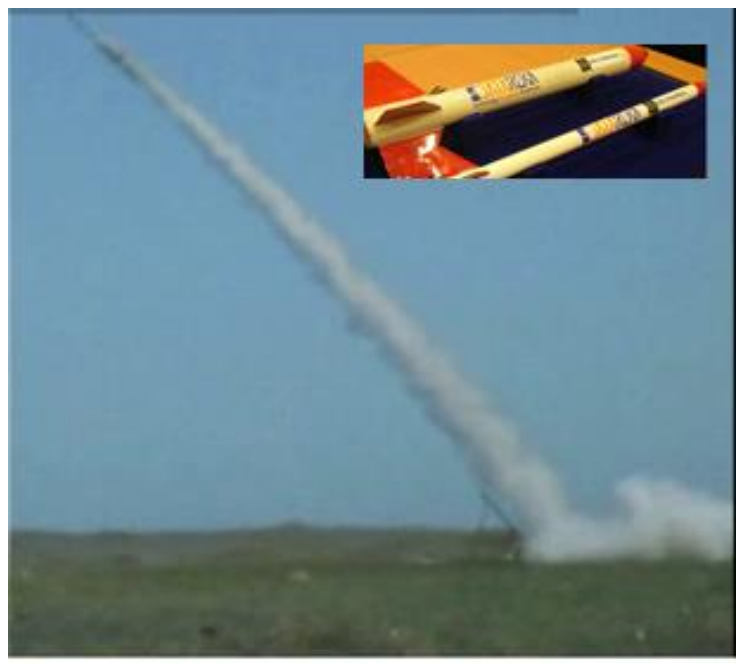

Fig. 19: Launching Test of Rocket Propellant on the Field

\section{CONCLUSION}

It can be concluded that:

1. Higher composition of oxidizer $\mathrm{KClO}_{4}$ produces higher flue gas velocity at the nozzle exit, higher thrust, total impulse, and specific impulse.

2. When $\mathrm{KClO}_{4}$ exceeds the amount of $\mathrm{KNO}_{3}$, it causes the propellant explode due to higher ignition thrust and pressure inside the tube.

3. The greater the density of the propellant, the longer the ignition time and the smaller the propellant burning rate are, but the smaller the total impulse, the specific impulse, and the thrust.

4. Low propellant density causes a faster burning rate, resulting in spontaneous burning of the propellant and explosion during the ignition process.

5. The greater the ratio of the diameter of the tube nozzle, the larger and faster thrust generated burning rate are. It also increases the specific impulse.

6. Overall optimum conditions obtained in this study is at the composition of $\mathrm{KClO}_{4}: \mathrm{KNO}_{3}$ equal to $1: 1\left(50 \% \mathrm{KClO}_{4}\right.$ in oxidizer), density of propellant 1.900 $\mathrm{gr} / \mathrm{cm}^{3}$ and nozzle diameter ratio $\left(\mathrm{Ae} / \mathrm{A}^{*}\right) 3.33$. 


\begin{tabular}{lll}
\hline ACKNOWLEGEMENT & $T c$ & $:$ burning temperature $\left({ }^{\circ} \mathrm{C}\right)$ \\
& $V$ & $:$ flow rate $(\mathrm{m} / \mathrm{s})$ \\
Great appreciation is addressed to & $V e$ & $:$ exhausted velocity $(\mathrm{m} / \mathrm{s})$ \\
Chemical Engineering Department, & $\rho$ & $:$ density $\left(\mathrm{g} / \mathrm{cm}^{3}\right)$ \\
Engineering Faculty, Gadjah Mada & $a$ & $:$ empirical coefficient of \\
University which has provided research & & propellant characteristics \\
facilities. \\
Appreciation and special thanks are also
\end{tabular}

\section{NOMENCLATURE}

\begin{tabular}{|c|c|c|}
\hline$A_{e}$ & & $\begin{array}{l}\text { cross sectional area at the } \\
\text { outer nozzle }\left(\mathrm{cm}^{2}\right) \text {. }\end{array}$ \\
\hline$A_{b}$ & & $\begin{array}{l}\text { surface area of propellant } \\
\left(\mathrm{cm}^{2}\right) \text {. }\end{array}$ \\
\hline $\mathrm{Ae} / \mathrm{A}^{*}$ & : & maksimum expansion ratio \\
\hline$d m / d t$ & : & rate of mass burning $(\mathrm{g} / \mathrm{s})$ \\
\hline$F$ & : & thrust $(\mathrm{N})$. \\
\hline$g$ & & gravitation $\left(\mathrm{m} / \mathrm{s}^{2}\right)$ \\
\hline$H$ & : & enthalphy (cal/g) \\
\hline$t_{b}$ & : & burning time (s) \\
\hline$I_{s p}$ & : & spesific impulse (s) \\
\hline$l_{t}$ & : & total impulse (N.s) \\
\hline$k$ & : & spesific heat ratio \\
\hline M & & $\begin{array}{l}\text { average molecullar weight } \\
\text { of gas-out }\end{array}$ \\
\hline$P c$ & & $\begin{array}{l}\text { pressure of burning space } \\
\left(\mathrm{kg} / \mathrm{cm}^{2}\right)\end{array}$ \\
\hline$P e$ & & $\begin{array}{l}\text { pressure at outer nozle } \\
\left(\mathrm{kg} / \mathrm{cm}^{2}\right)\end{array}$ \\
\hline$P_{0}$ & & $\begin{array}{l}\text { pressure in the chamber } \\
\text { tube }\left(\mathrm{kg} / \mathrm{cm}^{2}\right) .\end{array}$ \\
\hline$P_{a}$ & & $\begin{array}{l}\text { atmospheric } \\
\left(\mathrm{kg} / \mathrm{cm}^{2}\right)\end{array}$ \\
\hline$P_{e}$ & & $\begin{array}{l}\text { pressure at the outer noZzle } \\
\left(\mathrm{kg} / \mathrm{cm}^{2}\right) .\end{array}$ \\
\hline$R^{\prime}$ & & universal gas constant. \\
\hline 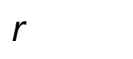 & & burning rate $(\mathrm{cm} / \mathrm{s})$ \\
\hline & & temperature $\left({ }^{\circ} \mathrm{C}\right)$ \\
\hline
\end{tabular}

\section{REFERENCES}

1. Bakhman, N.N., Belyaev, A.F., Kondrashkov, and Yu, A., 1974, "Effect of Metal Additives on Combustion Rate in Prototype Carburetion", Army Foreign Science and Technology Center, Charlottesville VA.

2. Douglas, H.W., Collins, J.H., Scortia, T.N., Cutforth, G.H., and Keller, R.B., 1971, "Solid Propellant Processing Factors in Motor Roket", Lewis Research Center CZeveZund, Ohio, NASA, Washington.

3. Douglas, H.W., Collins, J.H., Scortia, T.N., Cutforth, G.H., and Keller, R.B., 1972, "Solid Propellant Grain Design and Internal Balistics", Lewis Research Center CZeveZund, Ohio,NASA, Washington.

4. Douglas, H.W., Collins, J.H., Scortia, T.N., Cutforth, G.H., and Keller, R.B., 1973, "Solid Propellant Grain Structural Integrity Analysis", Lewis Research Center CZeveZund,Ohio, NASA, Washington.

5. James, R.J., Robert, A.S., and John, C.F., 1966, "Performance Of Rocket Nozzle Materials With Several Solid Propellants", Lewis Reseurch Center CZeveZund, Ohio, NASA, Washington. 
72 Optimization Study of the Solid Propellant (Rocket Fuel) Based on Extracted Bitumen of Indonesian Natural Buton Asphalt

6. Ja'afar, M.N.M., Ali, W.H.W., Dahlan, M.D.N., and Rizalman, M., 2009, "Propelan Pepejal Kalium Nitral Difabrikasi Kaidah Acuan Mampat", Journal Teknologim Universitas Teknologi Malaysia (In: Malayan)

7. Johnston, J.R., Signorezzi, R.A, and Freche, J.R., 1966, "Performance of Rocket Nozzle Materials With Several Solid Propellants", Lewis Reseurch Center, Czevezund, Ohio, NASA, Washington, p. 6.

8. Murachman, B., Purwono, S., dan Wintoko, J., 2009, "Laporan Rusnas UGM 2009: Propelan Padat Sebagai Bahan Pendorong Roket Menggunakan Bitumen Aspal Buton", Laboratorium Minyak Bumi dan Batubara, UGM, Yogyakarta.

9. Mugia. E, 1996, "Simulasi Uji Statik Motor Roket Propelan Padat", Program Magister Instrumentasi dan Kontrol, Program Pasca Sarjana, Institut Teknologi Bandung, Bandung.

10. Nuryanto, A., 2008,"Aspal Buton dan Propelan Padat", LAPAN, Jakarta.

11. Sarmidi, 1996, "Teknologi Roket untuk Perang dan Damai", Sinar Harapan, No. ISBN STTM7, Jakarta (In: Indonesia).
12. Sarner, S.F., 1966, "Propellant Chemistry", Reinhold Publishing Corporation, New York.

13. Sutton, G.P. dan Ross, D.M., 1976, "Rocket Propulsion Elements An Introduction to the Engineering of Rocket", John Wiley \& Sons, 4 edition, New York.

14. Sutrisno, 1997, "Pengaruh Elemen Aditif Terhadap Sifat-Sifat Propelan Padat Polibutadien-HTPB", Tesis S2 Jurusan Ilmu Material, Program Pasca Sarjana Universitas Indonesia, Jakarta.

15. Syarkawi, A., 2002, "Kinerja Propelan Padat Komposit Polibutadien dalam Kaitannya dengan Komposisi BahanBahannya", LAPAN, Jakarta.

16. Thiokol Propulsion (An Alcoa Business), 2000, Rocket Basics A Guide To Solid Propellant Rocketry, Brigham City, Utah.

17. Vesna, R. and Petric, M., 2005, "The Effect of Curing Agen on Solid Composite Rocket Propellant Characteristic", Scientific-Technical Review, Vol.LV, No.1, Beograd.

18. www.nakka-rocketry.net, Richard Nakka's Experimental Rocketry Web Site, accessed at 15 April 2010, 21.00 WIB 